\title{
PENDEKATAN PDCA DALAM KEGIATAN PEMANTAUAN PENGENDALIAN MUTU DI LEMBAGA KURSUS DAN PELATIHAN
}

\author{
Riyantini \\ e-mail: riyantinis@gmail.com \\ Dinas Pendidikan Kota Bandung
}

\begin{abstract}
Abstrak: Adanya tantangan untuk meningkatkan mutu Lembaga Kursus dan Pelatihan (LKP) sesuai 8 Standar Nasional Pendidikan, maka diperlukan adanya pendekatan yang berkaitan dengan fungsi manajemen; kegiatan perencanaan, pelaksanaan, pengecekan/evaluasi dan aksi perbaikan terhadap pengelolaan lembaga yang berkaitan dengan kualitas, maka dalam pelaksanaan kegiatan pengendalian mutu lembaga kursus dan pelatihan diterapkan pendekatan Plan Do Check and Act (PDCA). Rumusan masalah yang diajukan adalah bagaimana pendekatan PDCA dapat meningkatkan efektifitas kegiatan pemantauan dalam pengendalian mutu di lembaga kursus dan pelatihan. Tujuannya untuk mendeskripsikan impelementasi pendekataan PDCA di lembaga. Metode yang digunakan pendekatan deskriptif yang bersifat kualitatif dengan teknik pengumpulan data observasi, wawancara, didukung beberapa literatur yang berkaitan. Pendekatan PDCA berguna untuk penilik sebagai pola kerja dan untuk mengimplementasikan perubahan mutu dan mengukurnya serta melakukan perbaikan secara berkelanjutan. Kegiatan yang dilakukan penilik sebagai pengendali mutu program membuat komitmen bersama dengan pengelola, kemudian perencanaan, pelaksanaan, dan penilaian. Pendekatan PDCA dapat meningkatkan efektivitas pelaksanaan kegiatan pemantauan dalam pengendalian mutu lembaga kursus dan pelatihan.
\end{abstract}

Kata-kata kunci : pendekatan PDCA, penilik, pemantauan, pengendalian mutu LKP

\section{PDCA APPROACH IN MONITORING QUALITY CONTROL TOWARD COURSE AND TRAINING INSTITUTIONS}

\begin{abstract}
By having a challenge to escalate quality at course and training institutions (LKP) which is appropriate to 8 National Education Standards, it is necessary to have an approach related to management functions; planning, implementation, evaluation and improvement on institution management related to quality. Due to that reason, Plan Do Check and Act (PDCA) approach is implemented toward course and training institutions. Problem statement proposed is in what ways Plan Do Check and Act (PDCA) approach can escalate effectiveness in supervising the quality control at course and training institutions. The objective is to describe the implementation of PDCA approach at the institutions. The method used is a qualitative descriptive approach by conducting data observation to collect the data, interviews, and some related literature. PDCA approach which is useful for supervisors, can be used as work patterns, to implement quality changes, measure them, and improve the quality sustainably. Activities run by supervisors as quality controllers are making a commitment together with managers, planning, implementing, and assessing. This PDCA approach can escalate supervision effectiveness in controlling quality of course and training institutions.
\end{abstract}

Keywords: PDCA approach, overseer, monitoring, LKP quality control

\section{PENDAHULUAN}

Pendidikan berlangsung seumur hidup sejak dalam kandungan hingga ajal kematian menjemput, karenanya Sistem Pendidikan Nasional di Indonesia dilaksanakan pada tiga jalur yang terdiri dari "pendidikan formal, nonformal dan informal yang dapat saling melengkapi" (Pasal 13 UU No 20 tahun 2003).

Pendidikan nonformal (PNF) adalah 
jalur pendidikan di luar pendidikan formal yang dapat dilaksanakan secara terstruktur dan berjenjang, dengan fungsinya sebagai "Pelengkap (complementary), penambah (suplementary), dan pengganti (subtitution)" (Sudjana, 2010). Sementara UU No. 20 tahun 2003 pada pasal 26 menyebutkan "Pendidikan nonformal diselenggarakan bagi warga masyarakat yang memerlukan layanan pendidikan yang berfungsi sebagai pengganti, penambah, dan/ atau pelengkap pendidikan formal, dalam rangka mendukung pendidikan sepanjang hayat, berfungsi mengembangkan potensi peserta didik dengan penekanan pada penguasaan pengetahuan dan keterampilan fungsional serta pengembangan sikap dan kepribadian profesional."

Kebijakan pembangunan pendidikan nasional diarahkan untuk mewujudkan pendidikan yang berkeadilan, bermutu, dan relevan dengan kebutuhan baik lokal, nasional dan global sehingga mampu membangun insan Indonesia yang cerdas dan kompetitif. Untuk mewujudkan tujuan tersebut, maka dalam kebijakan penyelenggaraan pendidikan nasional bertumpu pada tiga pilar, yaitu 1) pemerataan dan perluasan akses; 2) peningkatan mutu, relevansi, daya saing; serta 3) peningkatan tata kelola, akuntabilitas, dan pencitraan publik, (Baswedan, Pidato Hardiknas 2015).

Pada jalur pendidikan nonformal, dalam mengimplementasikan kebijakan pembangunan pendidikan tersebut diperlukan adanya pendidik dan tenaga kependidikan. Salah satu tenaga kependidikan yang bergerak di bidang pendidikan nonformal adalah penilik. Peraturan Menteri Negara Pemberdayaan Aparatur Negara dan Reformasi Birokrasi Nomor 14 Tahun 2010 tentang Jabatan Fungsional Penilik dan Angka Kreditnya menjelaskan bahwa penilik adalah jabatan fungsional yang mempunyai ruang lingkup, tugas, tanggung jawab dan wewenang untuk melakukan pengendalian mutu dan evaluasi dampak program Pendidikan Anak Usia Dini (PAUD), Pendidikan Kesetaraan dan Keaksaraan, serta kursus pada jalur Pendidikan Nonformal dan Informal (PNFI) sesuai dengan peraturan perundang-undangan yang diduduki oleh Pegawai Negeri Sipil. Adapun tugas pokok dan fungsi penilik adalah merencanakan, memantau, menilai, membimbing, serta membina penyelenggaraan Program PAUD dan Dikmas yang terdiri dari Penilik PAUD, Penilik Pendidikan Kesetaraan dan Penilik Kursus. Agar dapat melaksanakan tugas pokok dan fungsi utamanya dalam melakukan kegiatan pengendalian mutu dan evaluasi dampak program PAUD dan Dikmas maka diperlukan pengetahuan dan keterampilan yang mendukung, sehingga apa yang ingin dicapai dalam Peraturan Menteri Pendayaan Aparatur Negara dan Reformasi Birokrasi Nomor 14 Tahun 2010 dapat berjalan dengan baik.

Ahyari (dalam Prihantoro, 2012) menyebutkan pengertian pengendalian mutu adalah segala aktivitas untuk menjaga dan mengarahkan agar mutu atau kualitas produk dapat dipertahankan sebagaimana yang telah direncanakan. Ravianto (dalam Prihantoro, 2012) juga menyebutkan proses pengendalian mutu adalah memutarkan siklus PDCA, yaitu melakukan perencanaan, pengerjaan atau proses, pengecekan atau evaluasi, dan aksi perbaikan terhadap masalah yang berkaitan dengan kualitas. Siklus PDCA merupakan penerapan konsep pengendalian mutu yang harus dilakukan secara maksimal pula.

Pengendalian mutu program pendidikan nonformal adalah proses memonitor melalui penilaian dan perbaikan agar hasilnya melebihkan harapan dan memuaskan pelanggan khususnya dalam bidang pendidikan nonformal. Dalam hal ini, pengendalian mutu program yang dilakukan oleh penilik pendidikan nonformal dan informal dimaksudkan agar program program yang dilakukan oleh lembaga pendidikan nonformal sesuai dengan standar pendidikan nasional sebagaimana diamanatkan dalam undangundang tentang Standar Nasional Pendidikan yang termasuk di dalamnya standar pendidikan nonformal.

Salah satu satuan pendidikan nonformal adalah lembaga kursus dan pelatihan yang diselenggarakan oleh masyarakat dengan tujuan menyelenggarakan dan menyediakan berbagai jenis pengetahuan, keterampilan dan sikap mental melalui proses pembelajaran dalam waktu singkat untuk mengembangkan diri, bekerja mencari nafkah dan atau melanjutkan ke tingkat/jenjang pendidikan yang lebih tinggi. Lembaga kursus dan pelatihan yang diselenggarakan masyarakat ini akan lebih baik dan dapat dipertanggungjawabkan jika dalam pengelolaan secara manajerial maupun pengelolaan dalam proses belajar dan pembelajarannya sesuai dengan standar yang telah ditentukan oleh pemerintah, sehingga dapat menghasilkan lulusan yang lebih kompeten dan berdaya guna di dunia kerja ataupun lulusan lembaga kursus dan pelatihan 
ini akan melanjutkan pendidikan ke jenjang yang lebih tinggi. Dengan demikian, diperlukan suatu sistem yang dapat menjamin mutu keberlangsungan penyelenggaraan Lembaga Kursus dan Pelatihan (LKP) di masyarakat yang lebih kredibel dan dapat dipertanggungjawabkan.

Adapun kegiatan pengendalian mutu yang dilakukan oleh penilik mencakup lima kegiatan pembinaan, yaitu (1) Pembinaan Pengelolaan Lembaga Kursus dan Pelatihan, (2) Pembinaan Pendidik dan Tenaga Kependidikan, (3) Pembinaan Program dan Perangkat Pembelajaran, (4) Pembinaan Organisasi Mitra, serta (5) Pendidikan Karakter dalam Kursus dan Pelatihan. Pengendalian mutu yang dilakukan penilik sesuai tugas pokok dan fungsinya akan berdampak positif terhadap kemajuan lembaga kursus dan pelatihan, karena banyak tantangan dan hambatan yang dihadapi oleh lembaga kursus dan pelatihan untuk dapat bersaing secara sehat. Ada beberapa macam tantangan serius yang dihadapi oleh lembaga kursus dan pelatihan yakni tantangan internal di dalam LKP, kondisi dalam negeri, dan kondisi luar negeri.

Berdasarkan data yang diperoleh dari Direktorat Jenderal Pendidikan Nonformal dan Informal Direkorat Pembinaan Kursus dan Kelembagaan pada Tahun 2010 bahwa (1) tantangan internal di LKP adalah jumlah LKP 13.747 dengan 22.571 jenis keterampilan yang diselenggarakan, hasil penilaian kinerja pada tahun 2009 dan 2010 di 1500 LKP: berkinerja A: 25 (1,6\%), B: $257(17,2 \%)$, C: 642 (41,6\%), D: 594 (39,6\%), akreditasi lembaga kursus belum berjalan (baru 443 akreditasi program), sarana dan prasarana terbatas cenderung ketinggalan, pendidik kursus yang sudah mengikuti pelatihan $23 \%$ (3.254 orang) dari 13.747 orang pengelola, standar kompetensi lulusan yang sudah disusun baru 25 jenis dari 70 jenis kursus prioritas; (2) tantangan kondisi dalam negeri, penduduk Indonesia saat ini 228 juta jiwa dengan angkatan kerja pada tahun 2009 sebanyak 113,74 juta jiwa dan tahun 2010 sebanyak 116 juta jiwa, pengangguran terbuka 8,56 juta terdiri dari tidak sekolah dan lulusan SD sebanyak 2,13 juta, lulusan SMP 1,66 Juta, lulusan SMU 2,11 Juta, lulusan SMK 1,34, lulusan Diploma 538,6 ribu, lulusan PT 8202 ribu (BPS 2010), perbandingan pengangguran di kota 5,15 juta jiwa atau $57,49 \%$, sedangkan pengangguran di desa sebanyak 3,41 juta jiwa atau $42,51 \%$, kemiskinan 32,53 juta (BPS 2009), sekitar $20 \%$ dari 300.000 lulusan perguruan tinggi di Indonesia setiap tahun menjadi pengangguran (Gatra, 2009) dan 1,7 juta anak DO, lulus SMU/ SMK/MA lulus dan tidak dapat melanjutkan ke PT (PSP 2009), terbatasnya lapangan pekerjaan di desa mendorong besarnya angka urbanisasi sehingga sumber daya alam di desa menjadi terlantar serta Indonesia masih menjadi negara importir tidak eksportir, walau sumber daya alam dan sumber daya manusianya melimpah; (3) tantangan kondisi luar negeri, persaingan global yang dimulai dengan AFTA kemudian MEA, penerapan berbagai standar mutu, tuntutan berbagai akreditasi dan sertifikasi berbagai produk dan jasa, membanjirnya lembaga kursus dan pelatihan dengan atribut "internasional" yang siap menyelenggarakan berbagai kursus dan pelatihan, banyaknya peluang kerja di luar negeri yang belum seluruhnya terpenuhi, cukup rendahnya kompetensi yang dimiliki TKI sehingga banyak menimbulkan masalah.

Berdasarkan kondisi di atas, tanpa ada upaya khusus maka LKP akan tinggal kenangan karena tiga hal, yaitu (1) kalah bersaing dengan lembaga luar negeri karena kalah modal dan kualitas sehingga tutup dan cukup jadi penonton, (2) lulusan LKP banyak yang tidak diakui kompetensinya sehingga menciptakan penggangguran juga, (3) LKP matisuri dan akan beraktivitas jika ada dana block grant. Pakar pendidikan nonformal memprediksi dalam hitungan 5 sampai 10 tahun jumlah lembaga kursus dan pelatihan akan berguguran dan diperkirakan hanya tinggal $40 \%$ dari jumlah yang ada sekarang apabila tidak dilakukan revitalisasi untuk memperkuat LKP.

Melihat kondisi tersebut sebenarnya kursus menjadi semakin strategis dengan dunia kerja untuk mengurangi angka penggangguran, dengan demikian pembinaan LKP tidak bisa dipisahkan dari beberapa hal, yaitu (1) penguatan lembaga penyelenggara kursus (LKP) dan penguatan pendidik; (2) tenaga kependidikan (persyaratan khusus yang diterapkan olah pasar kerja bisa dipenuhi dengan kursus dan banyaknya anak lulusan SD, SMP, SMA/MA yang tidak dapat melanjutkan sekolah dan angka drop out yang semakin bertambah); (3) penguatan dan inovasi program kursus serta perangkat pembelajaran; (4) penguatan jaringan kerja dan pembinaan organisasi mitra; (5) membentuk karakter; serta (6) pencitraan dan reformasi birokrasi dalam melayani masyarakat. Kondisi inilah yang menjadikan peranan kursus menjadi semakin strategis di dalam penyelarasan 
pendidikan pengelola. Hal tersebut merupakan pekerjaan rumah bagi penilik untuk senantiasa paham akan tugas pokok fungsinya sebagai pengendali mutu program.

Prihantoro (2012) menyatakan bahwa "Hakikatnya, siklus PDCA adalah suatu metode untuk melakukan perbaikan secara berkelanjutan'. Keunggulan dari siklus PDCA merupakan penerapan dari konsep pengendalian mutu dan untuk mendapatkan hasil yang maksimal, maka pengendalian mutu harus dilakukan secara maksimal pula. Caranya dengan menerapkan asas-asas pengendalian mutu melalui beberapa langkah yaitu tahap perencanaan (plan), pelaksanaan (do), pemeriksaan (check); dan tindakan perbaikan (action). Melalui siklus PDCA ini, diharapkan kegiatan pemantauan dalam pengendalian mutu yang dilaksanakan oleh penilik dalam bentuk pembinaan di lembaga kursus dan pelatihan dapat menjadi suatu sistem kendali yang efektif untuk mengkoordinasikan usaha penjagaan kualitas dan perbaikan mutu serta peningkatan kinerja secara berkesinambungan dan terus menerus terhadap lembaga kursus dan pelatihan (LKP).

Secara garis besar, dapat diidentifikasi bahwa diperlukan pendekatan atau cara yang sesuai dan mudah dilakukan oleh penilik dalam melaksanakan kegiatan pemantauan pengendalian mutu sehingga memperoleh hasil yang lebih efektif dan efisien berdasarkan jenjang jabatan yang dimilikinya. Upaya yang dapat dilakukan penilik adalah melaksanakan kegiatan pemantauan dalam pengendalian mutu sebagai suatu kegiatan sehingga diharapkan dapat menjadi perencana, pendorong, pengarah, fasilitator yang bersifat dinamis, dengan menerapkan pendekatan PDCA.

Secara pokok, penelitian ini mengemukakan beberapa identifikasi permasalahan, yaitu (1) pelaksanaan kegiatan pemantauan dalam pengendalian mutu di satuan program PAUD dan Dikmas khususnya di lembaga kursus dan pelatihan (LKP) belum maksimal, (2) tenaga kependidikan yang memiliki kemampuan dalam pengelolaan kegiatan pemantauan dalam pengendalian mutu, terutama pemahaman tentang metoda pemantauan terhadap satuan program PAUD dan Dikmas dengan menggunakan pendekatan PDCA kurang memadai, serta (3) implementasi pendekatan PDCA dalam pengelolaan pemantauan pengendalian mutu pada upaya peningkatan kinerja LKP belum maksimal digunakan.

Berdasarkan latar belakang masalah dan identifikasi masalah tersebut, terdapat beberapa rumusan masalah pada penelitian ini, yaitu (1) bagaimana kegiatan perencanaan pemantauan pengendalian mutu di LKP dengan menggunakan pendekatan PDCA? (2) bagaimana kegiatan pelaksanaan pemantauan pengendalian mutu di LKP dengan menggunakan pendekatan PDCA? (3) bagaimana kegiatan penilaian hasil pemantauan pengendalian mutu layanan di LKP dengan menggunakan pendekatan PDCA? serta (4) bagaimana hasil pelaksanaan pemantauan pengendalian mutu layanan di LKP dengan pendekatan PDCA?

Adapun tujuan umum pada penelitian ini adalah mendeskripsikan pendekatan PDCA dapat meningkatkan efektivitas pengelolaan kegiatan pemantauan pengendalian mutu lembaga kursus dan pelatihan. Tujuan khusus penelitian adalah (1) untuk mendeskripsikan kegiatan perencanaan pemantauan pengendalian mutu di LKP dengan menggunakan pendekatan PDCA, (2) untuk mendeskripsikan kegiatan pelaksanaan pemantauan pengendalian mutu LKP dengan menggunakan pendekatan PDCA, (3) untuk mendeskripsikan kegiatan penilaian hasil pemantauan pengendalian mutu LKP dengan menggunakan pendekatan PDCA, serta (4) untuk mendeskripsikan hasil pelaksanaan pemantauan pengendalian mutu di LKP dengan pendekatan PDCA.

Definisi operasional yang dipergunakan dalam penulisan adalah (1) kegiatan pemantauan dalam pengendalian mutu adalah proses memonitor melalui penilaian dan perbaikan agar hasilnya melebihkan harapan dan memuaskan pelanggan khususnya dalam bidang pendidikan nonformal yang terdiri dari empat kegiatan, yaitu kegiatan pelaksanaan, kegiatan penilaian dan hasil kegiatan pengelolaan pengendalian mutu layanan; (2) pendekatan PDCA adalah singkatan bahasa Inggris dari "Plan, Do, Check, Act (Rencanakan, Kerjakan, Cek, Tindak Lanjut) diartikan sebagai suatu proses pemecahan masalah empat langkah interaktif yang umum digunakan dalam pengendalian kualitas yang pada hakikatnya dilakukan utuk melakukan perbaikan secara berkelanjutan sehingga pengelolaan pengendalian mutu layanan di satuan program PAUD dan Dikmas lebih meningkat; (3) lembaga kursus dan pelatihan adalah satuan pendidikan 
nonformal yang diselenggarakan bagi masyarakat yang memerlukan bekal pengetahuan, keterampilan, kecakapan hidup dan sikap untuk mengembangkan diri, mengembangkan profesi bekerja, usaha mandiri dan atau melanjutkan pendidikan ke jenjang yang lebih tinggi; serta (4) asumsi adalah anggapan yang diterima sebagai kebenaran, diuji dari keseringannya terjadi di masyarakat (reliability), keajegannya terjadi di masyarakat (konsistensi), dan kebenarannya diterima oleh umum (valid).

Asumsi pengelolaan kegiatan pemantauan pengendalian mutu yaitu (a) pengendalian mutu adalah segala aktivitas untuk menjaga dan mengarahkan agar mutu atau kualitas produk dapat dipertahankan sebagaimana yang telah direncanakan, sedangkan proses pengendalian mutu adalah memutarkan siklus PDCA, yaitu dengan melakukan prinsip manajemen yang meliputi perencanaan, pengerjaan atau proses, pengecekan atau evaluasi dan aksi perbaikan terhadap masalah yang berkaitan dengan kualitas; (b) upaya dalam meningkatkan kualitas LKP salah satunya adalah melalui pembinaan dan pembimbingan dengan harapan pembinaan ini dapat menekan biaya tinggi dalam pelaksanaannya dan memiliki dampak yang cukup tinggi pada perubahan pengelolaan LKP serta dapat melibatkan semua unsur yang bertugas dalam menjamin mutu lembaga pendidikan yang memiliki kepentingan untuk meningkatkan kualitas LKP; serta (c) salah satu bentuk satuan pendidikan yang diselenggarakan masyarakat adalah lembaga kursus dan pelatihan, dengan maksud untuk mengakses kebutuhan masyarakat yang memerlukan bekal untuk mengembangkan diri, memiliki keterampilan agar dapat bekerja mencari nafkah dan/atau untuk melanjutkan ke jenjang yang lebih tinggi, maka dari itu, lembaga kursus dan pelatihan harus memiliki standar minimal pelayanan relevansinya dengan kebutuhan dan/atau kondisi masyarakat sehingga efektivitas, efisiensi, dan akuntabilitas pengelolaan pendidikan dapat diakui oleh masyarakat sebagai penguna jasa.

Konsep PDCA cycle pertama kali dikenalkan oleh Walter Shewhart pada tahun 1930 yang disebut dengan "Shewhart Cycle", selanjutnya, konsep ini dikembangkan oleh Dr. Walter Edwards Deming yang kemudian dikenal dengan "The Deming Wheel". PDCA cycle atau siklus PDCA berguna sebagai pola kerja dalam perbaikan suatu proses atau sistem (Akhyar, 2008).
Menurut Hardjosoedharmo (dalam Prihantoro, 2012), siklus PDCA merupakan cara yang sistematis untuk menambah pengetahuan mengenai proses dalam organisasi atau lembaga dan menambah pengetahuan untuk mengimplementasikan perubahan mutu serta bagaimana mengukurnya. Manfaat dari Siklus PDCA adalah (1) untuk memudahkan pemetaan wewenang dan tangggungjawab dari sebuah unit organisasi, (2) sebagai pola kerja dalam perbaikan suatu proses atau sitem di sebuah organisasi, (3) untuk menyelesaikan serta mengendalikan permasalahan dengan pola yang runtun dan sistematis, (4) untuk kegiatan continus improvement dalam rangka memperpendek alur kerja, serta (5) menghapuskan pemborosan di tempat kerja dan meningkatkan produktivitas.

Siklus PDCA merupakan penerapan dari konsep pengendalian mutu dan ada konsep problem solving yang dapat diterapkan di organisasi atau lembaga dengan menggunakan pendekatan PDCA sebagai proses penyelesaian masalah, dengan pola dan runtun yang sistematis. Langkah-langkah pada masing-masing tahapan pada proses PDCA adalah (1) tahap perencanaan (plan), terdiri dari beberapa langkah, yaitu a) harus ditentukan proses mana yang perlu diperbaiki yaitu proses yang berkaitan dengan misi lembaga dan tuntutan konsumen atau pelanggan, b) menentukan perbaikan apa yang akan dilakukan terhadap proses yang dipilih, c) menentukan data dan informasi yang diperlukan untuk memilih proses yang paling relevan dengan lembaga/perusahaan; (2) tahap pelaksanaan (do), terdiri dari beberapa langkah, yaitu (a) mengumpulkan informasi dasar tentang jalannya proses yang sedang berlangsung, (b) melakukan perubahan yang dikehendaki untuk dapat diterapkan dengan menyesuaikan keadaan nyata yang ada dan tidak menimbulkan gejolak, (c) kembali mengumpulkan data untuk mengetahui apakah perubahan telah membawa perbaikan atau tidak; (3) tahap pemeriksaan (check), terdiri dari beberapa langkah, yaitu (a) memantau, (b) mengevaluasi proses dan hasil terhadap sasaran dan spesifikasi dengan teknik observasi dan survey, (c) melaporkan hasilnya; serta (4) tahap tindakan perbaikan $(A c t)$, terdiri dari beberapa langkah, yaitu (a) menindaklanjuti hasil untuk perbaikan yang diperlukan yang berarti meninjau seluruh langkah dan memodifikasi proses untuk memperbaikinya, (b) menindaklanjuti hasil yang berarti melakukan standarisasi perubahan seperti merevisi proses yang 
sudah diperbaiki, memodifikasi standar, prosedur dan kebijakan yang ada.

Konsep pengendalian mutu adalah suatu pemikiran dasar untuk menilai hasil yang ingin dicapai dalam pelaksanaan proses kegiatan produk atau jasa (produsen) untuk mewujudkan mutu produk atau jasa yang berkesinambungan dalam konteks memenuhi kebutuhan dan kepuasan pelanggan. Pada saat ini, konsep pengendalian mutu banyak dimanfaatkan oleh perusahaan untuk menjaring pelanggannya dengan "cara memberikan yang terbaik". Konsep pengendalian mutu adalah cara yang tepat demi tercapainya tujuan perusahaan "memberikan yang terbaik".

Pengendalian mutu program pendidikan nonformal sebagai bagian atau jalur dalam pendidikan nasional tidak terlepas dari pengendalian dalam bidang bisnis, hal ini disebabkan banyak dikembangkan dan banyak diterapkan dalam bidang bisnis sampai batas tertentu. Ada beberapa persamaan antara pendidikan termasuk pendidikan nonformal dengan industri. Suatu industri memproduksi suatu barang, sedangkan pendidikan memproduksi lulusan. Jenis dan kualitas barang yang diproduksi industri harus memenuhi standar mutu agar dapat diterima dan mampu bersaing di pasaran, demikian juga dengan pendidikan, macam dan kualitas Iulusan harus sesuai dan memenuhi tuntutan penggunaan, dengan kata lain pengendalian mutu program merupakan suatu keharusan yang dipahami oleh semua pihak, karena pengendalian mutu berkaitan dengan kepuasan dari pengguna. Agar proses pendidikan dapat berjalan dengan efektif dan effisien, maka diperlukan adanya manajemen.

Berdasarkan uraian tersebut, maka ada tiga kata yang perlu dipahami, yaitu (1) pengendalian (controlling), menurut Ahyari (dalam Prihantoro, 2012), pengendalian adalah segala aktivitas untuk menjaga dan mengarahkan agar mutu atau kualitas produk dapat dipertahankan sebagaimana yang telah direncanakan, demikian halnya yang dikatakan oleh Schermerhon yang dikutip oleh Hiryanto (2010) menyatakan "Controlling as a process of monitoring performance and taking action to ensur desires result' dimana sasaran dari pengendalian adalah ketercapaian hasil yang diharapkan dan pencapaian hasil ini dilakukan melalui monitoring dan kegiatan perbaikan, dengan demikian controlling adalah proses untuk memastikan kegiatan yang sedang berjalan sesuai dengan apa yang direncanakan; (2) konsep mutu, menurut Fattah (2012), mutu adalah kemampuan (ability) yang dimiliki oleh suatu produk atau jasa (services) yang dapat memenuhi kebutuhan, harapan, dan kepuasan pelanggan yang dalam pendidikan dikelompokkan menjadi dua yaitu internal customer (siswa sebagai pebelajar) dan eksternal customer (masyarakat dan dunia industri); (3) program pendidikan nonformal/PAUD dan Dikmas, dalam Undang-Undang Nomor 20 Tahun 2003 tentang Sistem Pendidikan Nasional, khususnya pendidikan nonformal meliputi pendidikan kecakapan hidup, pendidikan anak usia dini, pendidikan kepemudaan, pendidikan pemberdayaan perempuan, pendidikan keaksaraan, pendidikan kesetaraan, pendidikan keterampilan dan pelatihan kerja, serta pendidikan lain yang ditujukan untuk mengembangkan kemampuan peserta didik.

Berdasarkan pengertian tersebut, maka pengendalian mutu program pendidikan nonformal adalah proses memonitor, melalui penilaian dan perbaikan agar hasilnya melebihkan harapan dan memuaskan pelanggan khususnya di bidang pendidikan nonformal. Dalam hal ini, pengendalian mutu program pendidikan nonformal dilakukan oleh penilik sebagai Pengendali Mutu Program PAUD dan Dikmas.

Berdasarkan Peraturan Menteri Pendayagunaan Aparatur Negara dan Reformasi Birokrasi Nomor 14 Tahun 2010, yang dimaksud dengan Jabatan Fungsional Penilik adalah jabatan fungsional yang mempunyai ruang lingkup, tugas, tanggung jawab dan wewenang untuk melakukan kegiatan pengendalian mutu dan evaluasi dampak program pendidikan anak usia dini (PAUD), pendidikan kesetaraan dan keaksaraan, serta kursus pada jalur pendidikan nonformal dan informal (PNFI) melalui kegiatan merencanakan, pemantauan, penilaian, pembimbingan dan pembinaan serta evaluasi dampak yang diduduki oleh Pegawai Negeri Sipil. Penilik adalah tenaga kependidikan dan pelaksana teknis fungsional dengan tugas utamanya melakukan kegiatan pengendalian mutu dan evaluasi dampak program pendidikan anak usia dini (PAUD), pendidikan kesetaraaan dan keaksaraan, serta kursus pada jalur pendidikan nonformal dan informal (PNFI). Kursus dan pelatihan adalah proses pembelajaran yang diselenggarakan bagi masyarakat yang memerlukan bekal pengetahuan, keterampilan, kecakapan hidup dan sikap mengembangkan diri, 
mengembangkan profesi, bekerja, usaha mandiri, dan/atau melanjutkan pendidikan ke jenjang yang lebih tinggi.

Pada Pasal 4 Permen PAN dan RB Nomor 14 Tahun 2010 tentang Tugas Pokok dan Fungsi Penilik adalah melaksanakan kegiatan pengendalian mutu dan evaluasi dampak program PNFI/ PAUD dan Dikmas. Tugas pokok penilik dalam pengelolaan pengendalian mutu program PAUD dan Dikmas adalah (1) perencanaan program pengendalian mutu, (2) pelaksanaan pemantauan program PAUD dan Dikmas, (3) pelaksanaan penilaian program PAUD dan Dikmas, (4) pelaksanaan pembimbingan dan pembinaan kepada pendidik dan tenaga kependidikan pada satuan PAUD dan Dikmas, serta (5) penyusunan laporan hasil pengendalian mutu PAUD dan Dikmas.

Menurut Peraturan Menteri Pendidikan dan Kebudayaan Nomor 81 Tahun 2013, tentang Satuan Pendidikan Nonformal, bahwa satuan Pendidikan Nonformal terdiri dari (1) Lembaga Kursus dan Pelatihan, (2) Kelompok Belajar, (3) PKBM, (4) Majelis Taklim, dan (5) Satuan PNF sejenis yang terdiri dari Rumah Pintar, balai belajar bersama, lembaga bimbingan belajar serta bentuk lain yang berkembang di masyarakat dan ditetapkan oleh Direktur Jenderal Pendidikan Anak Usia Dini, Nonformal dan Informal.

LKP sebagai satuan pendidikan nonformal dapat menyelenggarakan lebih dari satu program kursus, yang perlu dihindari adalah kesalahpahaman masyarakat yang seringkali mendirikan satuan pendidikan nonformal di bawah satuan pendidikan nonformal lainnya. Lembaga Kursus dan Pelatihan adalah satuan pendidikan nonformal yang diselenggarakan bagi masyarakat yang memerlukan bekal pengetahuan, keterampilan, kecakapan hidup dan sikap untuk mengembangkan diri, mengembangkan profesi bekerja, usaha mandiri, dan atau melanjutkan pendidikan ke jenjang yang lebih tinggi.

Berdasarkan pemenuhan delapan Standar Nasional Pendidikan Lembaga Kursus dan Pelatihan diklasifikasi dalam empat kategori, yaitu (1) LKP Rintisan adalah LKP yang sudah memenuhi persyaratan minimal sebagai lembaga untuk menyelenggarakan kegiatan pembelajaran, baru merintis penyelenggaraan penididikan minimal; (2) LKP dengan Standar Pelayanan Minimal adalah LKP yang telah memiliki persyaratan minimal; (3) LKP dengan Standar Nasional Pendidikan adalah LKP yang telah memiliki persyaratan memenuhi Standar Nasional Pendidikan, meliputi standar isi, standar proses, standar kompetensi lulusan, standar pendidik dan tenaga kependidikan, standar sarana dan prasarana, standar pengelolaan, standar pembiayaan, dan standar penilaian; serta (4) LKP dengan Standar Internasional adalah LKP yang sudah memenuhi persyaratan sebagai LKP berklasifikasi nasional dan diperkaya dengan ciri-ciri yang mengacu pada keunggulan yang dipersyaratkan untuk memiliki daya saing di tingkat internasional.

Penelitian ini berfokus pada fungsi manajemen yaitu pengelolaan yang terdiri dari perencanaan, pelaksanaan/pengorganisasian, penilaian, hasil pembinaan kerja, dan pengawasan. Hal tersebut tidak terlepas dari tugas pokok fungsi penilik sebagai pengelola pengendali mutu layanan program LKP di wilayah binaannya masing masing.

\section{METODE PENELITIAN}

Berdasarkan permasalahan penelitian, maka pendekatan yang digunakan adalah kualitatif. Pendekatan kualitatif merupakan prosedur penelitian dengan menghasilkan penelitian deskriptif yang berupa kata-kata tertulis atau lisan dari orang-orang dan prilaku yang diamati, yang pada dasarnya memiliki landasan teoretis bertumpu secara mendasar pada fenomenologi dan menggali makna penelitian.

Penelitian ini dilaksanakan sesuai dengan program kerja tahunan dan triwulan penilik, yaitu pada triwulan 1, 2, 3, dan 4 tahun 2016. Berlokasi di Kecamatan Sukasari dan Cidadap Kota Bandung, sebanyak 10 lembaga kursus dan pelatihan.

Penelitian ini menggunakan beberapa metode untuk mendapatkan data yang lebih akurat sebagai dasar pengambilan keputusan agar mendapat pemecahan masalah yang tepat, untuk mengetahui apakah pendekatan PDCA dapat meningkatkan efektivitas pengelolaan kegiatan pemantauan pengendalian mutu lembaga kursus dan pelatihan.

Secara umum, penelitian ini bertujuan untuk mengamati, mengkaji, menganalisis dan mendapatkan gambaran tentang efektivitas 
pendekatan PDCA. Studi kasus termasuk dalam penelitian analisis desktriptif, yaitu penelitian yang dilakukan terfokus pada suatu kasus tertentu untuk diamati dan dianalisis secara cermat sampai dengan tuntas. Kasus yang dimaksud biasanya berupa tunggal atau jamak, misalnya berupa individu atau kelompok. Di sini perlu dilakukan analisis secara tajam terhadap berbagai faktor yang terkait dengan kasus tersebut sehingga akan diperoleh kesimpulan yang akurat. Penelitian ini memusatkan diri pada suatu objek tertentu yang mempelajarinya sebagai suatu kasus. Data studi kasus dapat diperoleh dari semua pihak yang bersangkutan, dengan kata lain, data dalam studi ini dikumpulkan dari berbagai sumber. Lebih lanjut, menurut Creswell dalam Sugiyono (2015) mengemukakan bahwa studi kasus atau studi lapangan adalah merupakan salah satu jenis penelitian kualitatif, dimana peneliti melakukan eksplorasi secara mendalam terhadap program, kejadian, proses, aktivitas, terhadap satu atau lebih orang. Suatu kasus terikat oleh waktu dan aktivitas, sehingga dalam penelitian ini dilakukan pengumpulan data secara mendetail dengan berbagai prosedur pengumpulan data secara mendetail dan berkesinambungan. Menurut Bogdan dan Biken (dalam Sugiyono, 2015), studi kasus atau studi lapangan merupakan pengujian secara rinci terhadap suatu latar atau satu orang subjek atau satu tempat penyimpangan dokumen atau peristiwa tertentu.

Dalam penelitian ini tercatat bahwa proses pengelolaan pengendalian mutu layanan harus sesuai sasaran dan strategi atau pendekatan apa yang dapat digunakan dalam meningkatkan efektivitas pengelolaan pengendalian mutu lembaga kursus dan pelatihan, terkait dengan masalahmasalah yang muncul dengan objek yang diteliti. Kemudian masalah ini dideskripsikan apa adanya sesuai dengan temuan di lapangan. Data yang diperoleh dari wawancara bertujuan agar peneliti tidak melakukan kesalahan dalam menganalisis data, kemudian data yang diperoleh dan dikumpulkan bersifat verbal dan nonverbal. Wawancara dilakukan langsung kepada Kepala Seksi Kursus dan Kelembagaan Dinas Pendidikan Kota Bandung, Penilik dan Pimpinan LKP.

Data verbal hasil wawancara dilengkapi, diperkuat dan disempurnakan dengan metode lain seperti observasi yang merupakan suatu metode pengumpulan data melalui pengamatan terhadap objek penelitian, baik langsung maupun tidak langsung. Instrumen yang digunakan dalam pengumpulan data adalah a) instrumen pengumpul data yang mengacu pada 8 standar nasional pendidikan dan b) instrumen pemantauan bidang akademik dan manajerial sesuai dengan Permen PAN dan RB Tahun 2014 Tahun 2010. Metode dokumentasi juga dilakukan sebagai pelengkap dalam pengumpulan data dengan tujuan untuk memperoleh data tertulis mengenai objek yang diteliti secara akurat. Adapun studi dokumentasi yang dilakukan adalah melalui pengamatan dokumen administrasi yang dimiliki lembaga kursus dan pelatihan.

\section{HASIL DAN PEMBAHASAN}

\section{Hasil}

Kegiatan pemantauan dengan pendekatan PDCA di lembaga kursus dan pelatihan yang berada di wilayah Kecamatan Sukasari dan Cidadap Kota Bandung selama tahun 2016 adalah (1) Kegiatan perencanaan pemantauan pengendalian mutu LKP yaitu diawali dengan menyusun rencana kerja tahun 2016, rencana kerja triwulan 1 (Januari, Februari, dan Maret), triwulan 2 (April, Mei, dan Juni), triwulan 3 (Juli, Agustus, dan September), triwulan 4 (Oktober, November, dan Desember), pengendalian mutu program LKP, dilanjutkan menyusun jadwal kunjungan awal pengelola lembaga kursus dan pelatihan sesuai komitmen bersama antara penilik dan pengelola yang dituangkan dalam program kunjungan ke lembaga yang disebut sebagai visitasi, kemudian melakukan kegiatan pemantauan sesuai dengan jadwal yang telah disepakati bersama dalam jangka waktu satu triwulan yang telah ditetapkan sebelumnya. Kegiatan pemantauan dilakukan secara terus menerus agar membuahkan hasil yang dapat dinilai, pelaksanaan pemantauan dilakukan tiga kali kunjungan ke lembaga dan satu kali dilaksanakan evaluasi, apabila ditemukan penyimpangan-penyimpangan yang berarti, baik bidang akademik maupun manajerial dalam kegiatan pemantauan akan terus dilakukan pembinaan secara terus-menerus dan berkesinambungan dengan 
tujuan memudahkan pencapaian sasaran dan mengevaluasi kegiatan yang dilakukan Penilik; (2) kegiatan pelaksanaan pengendalian mutu untuk proses kegiatan pemantauan program LKP dimulai dengan kegiatan membuat instrumen pemantauan program, mengumpulkan data hasil pemantauan program yang diklasifikasikan menurut jenis hambatan-hambatan yang ada di satuan pendidikan (adanya peningkatan secara signifikan pada standar isi, standar sarana prasarana, dan standar peserta didik), menganalisis hasil pemantauan program untuk mengetahui pemecahan masalah yang dapat dilakukan oleh penilik sebagai sumber masukan dan perbaikan selanjutnya (hambatannya adalah terdapat lembaga yang belum mencapai standar yang telah ditetapkan, standar pendidik dan tenaga kependidikan yang belum sesuai dengan kualifikasi pendidikan sebagai tenaga pengelola dan tenaga pendidikan di lembaga), menyusun laporan hasil pemantauan program yang dilakukan secara rutin dan berkesinambungan berdasarkan data yang telah dihimpun dan dianalisis oleh penilik dengan tujuan sebagai bahan masukan atau pertimbangan dalam pengendalian mutu program pendidikan nonformal; (3) kegiatan penilaian hasil pemantauan pengendalian mutu di LKP dilakukan secara komprehensif dan berkesinambungan yang dimulai dari tahap perencanaan hingga penilaian/ pemeriksaan, sehingga apa yang akan dilakukan untuk menemukan langkah selanjutnya akan sesuai dengan tujuan semula yaitu untuk memperbaiki atau memecahkan masalah yang ada di lembaga sehingga ada perubahan yang positif terhadap seluruh komponen yang berada di lembaga tersebut, kegiatan pemeriksaan atau penilaian terhadap perubahan yang telah dilksanakan oleh lembaga dilakukan bersama sama; (4) hasil pelaksanaan pemantauan pengendalian mutu di LKP dengan pendekatan PDCA memiliki pengaruh yang positif, artinya peran pendekatan PDCA memiliki pengaruh yang kuat terhadap perubahan pengelolaan lembaga, dimana perbaikan dilakukan berdasarkan perencanaan dengan identifikasi masalah terlebih dahulu dilanjutkan dengan pelaksanaan perbaikan sesuai kemampuan dan sumber daya manusia yang ada di lembaga sehingga tidak menimbulkan gejolak, pendekatan PDCA dalam pengendalian mutu LKP yang diamati oleh peneliti selama kurang lebih tiga bulan memberikan respon yang baik yang ditandai dengan meningkatnya jumlah peserta didik sebagai pengguna jasa lembaga kursus dan pelatihan.

\section{Pembahasan}

Efektif tidaknya kegiatan pemantauan yang dilakukan di satuan pendidikan nonformal tergantung pada pelaku utama yaitu penilik, dengan memperhatikan beberapa prinsip, yaitu (1) teliti, artinya informasi yang diperoleh harus benar; (2) berkala, artinya informasi diperoleh secara berkala sehingga usaha perbaikan dilakukan berkala juga; (3) objektif dan komprehensif, artinya hasil pemantauan dapat dipahami oleh semua orang yang terlibat; (4) terfokus pada satu titik kegiatan pemantauan; (5) realistik, kegiatan dapat dilakukan dengan mudah; (6) fleksibel, kegiatan pemantauan cukup lentur dalam menghadapi kemungkinan kemungkinan diluar dugaan; (7) perspektif dan operasional, kegiatan pemantauan dapat menunjukkan tindakan yang harus dilakukan; serta (8) dapat diterima oleh seluruh elemen yang terlibat.

Melalui penjelasan tersebut, kegiatan pemantauan diharapkan dapat menjadi lebih mudah dilakukan dalam pengendalian mutu program lembaga kursus dan pelatihan sesuai dengan teori yang digunakan yaitu konsep yang dikembangkan oleh Dr. Walter Edward Deming yang dikenal dengan "The Deming Wheel". Siklus Plan Do Check and Act (PDCA) berguna sebagai pola kerja dalam sistem organisasi atau lembaga dan menambah pengetahuan untuk mengimplementasikan perubahan mutu serta mengukurnya dan melakukan perbaikan secara berkelanjutan. Keterlibatan penilik sebagai pengendali mutu satuan Program PAUDNI khususnya di lembaga kursus dan pelatihan sangat dibutuhkan yaitu dalam kegiatan perencanaan, pelaksanaan, pemeriksaan/penilaian, dan hasil pengelolaan pengendalian mutu di LKP dengan menggunakan pendekatan PDCA.

Plan, perencanaan kegiatan pemantauan yang dilakukan penilik adalah menyusun rencana tahunan pengendalian mutu program, menyusun rencana kerja triwulan pengendalian mutu program, dilanjutkan menyusun jadwal kunjungan awal dengan pengelola lembaga kursus dan pelatihan sesuai komitmen bersama antara penilik dan pengelola yang dituangkan dalam program kunjungan ke lembaga, kegiatan kunjungan awal ini peneliti sebutkan sebagai visitasi.

Do, pelaksanaan pemantauan program satuan pendidikan nonformal, dimulai dengan kegiatan membuat instrumen pemantauan program, 
mengumpulkan data pemantauan program, menganalisis hasil pemantauan program, serta menyusun laporan hasil pemantauan program.

Check, tahap penilaian adalah merangkum seluruh hasil data dari instrumen yang disusun untuk mengetahui kendala-kendala yang dihadapi lembaga kemudian diberikan bimbingan sebagai tindak lanjut kegiatan pemantauan.

Action, tahap tindakan perbaikan adalah melakukan analisis terhadap data yang diperoleh oleh penilik dalam melakukan kegiatan pemantauan pengendalian mutu di lembaga kursus dan pelatihan secara berkesinambungan, artinya setelah penilik memiliki cukup data kekurangan dan kelemahan lembaga kemudian dicarikan pemecahan masalahnya sehingga meminimalisisr permasalahan yang ada di lembaga.
Kegiatan pemantauan yang dilakukan penilik ini telah dilakukan selama satu Triwulan dan hasilnya berdampak pada pada lembaga yaitu (1) Lembaga Kursus dan Pelatihan di Kecamatan Cidadap Kota Bandung ingin terus dilakukan pembinaan; (2) Lembaga Kursus dan Pelatihan di Kecamatan Cidadap Kota Bandung dapat membuat laporan kegiatan dengan rutin; (3) penilik dapat melibatkan tiga perannya sekaligus dalam satu kegiatan saja; (4) penilik tidak mengalami kesulitan dalam memperoleh informasi perkembangan lembaga kursus dan pelatihan; (5) terjalinnya kerjasama yang sinergis antara penilik dan Lembaga Kursus dan Pelatihan; (6) terjadinya peningkatan Kinerja Lembaga Kursus dan Pelatihan; serta (7) akuntabilitas Lembaga Kursus dan Pelatihan oleh masyarakat.

\section{PENUTUP}

\section{Kesimpulan}

Setelah melakukan penelitian dan menganalis tentang efektivitas pendekatan PDCA dalam kegiatan pemantauan pengendalian mutu LKP di Kota Bandung dengan mengacu pada delapan standar nasional pendidikan, dari hasil analisis dan pembahasan penelitian dapat disimpulkan bahwa pendekatan PDCA dapat meningkatkan efektivitas kegiatan pemantauan pengendalian mutu lembaga kursus dan pelatihan. Secara lebih terperinci dapat disimpulkan (1) kegiatan perencanaan pemantauan di lembaga harus menentukan terlebih dahulu proses mana yang harus diperbaiki, selanjutnya menentukan pula langkah perbaikan apa yang akan dilakukan terhadap proses yang telah dipilih sebelumnya; (2) kegiatan pelaksanaan pemantauan di lembaga diawali dengan mengumpulkan informasi kembali tentang jalannya proses yang sedang berlangsung di lembaga, kemudian dilakukan perubahan yang telah ditetapkan untuk dapat diterapkan dilanjutkan dengan mengumpulkan data kembali untuk mengetahui apakah perubahan telah membawa perbaikan atau tidak, artinya memberikan kontribusi yang positif terhadap lembaga; (3) kegiatan pemeriksaan/penilaian kegiatan pemantauan di lembaga dilakukan secara keseluruhan melalui pemantauan dan mengevaluasi proses dan hasil terhadap sasaran serta melaporkan hasilnya; serta (4) hasil pelaksanaan kegiatan pemantauan di lembaga memberikan kontribusi yang positif dalam keberhasilan pengelolaan kegiatan pemantauan pengendalian mutu yang dilakukan penilik, sehingga terjadi perubahan yang berarti dalam pengelolaan lembaga kursus dan pelatihan dengan melibatkan seluruh komponen yang ada di lembaga.

\section{Saran}

Berdasarkan hasil penelitian pendekatan PDCA dalam kegiatan pengendalian mutu lembaga kursus dan pelatihan di Kota Bandung, penulis merekomendasikan, pertama, kepada lembaga kursus dan pelatihan (LKP) bahwa kegiatan pengendalian mutu akan bergantung pada 1) proses perencanaan yang didalamnya sudah ditentukan proses mana yang akan diperbaiki dan ditindaklanjuti oleh lembaga sesuai bimbingan dari penilik, seperti a) proses pelaksanaan, setelah diketahui prioritas proses yang akan dilaksanakan dan ditindaklanjuti maka lembaga berkewajiban untuk melakukan perubahan-perubahan pada proses tersebut, b) proses pemeriksaan dan penilaian yang bermanfaat untuk mengevaluasi seluruh proses perbaikan yang telah dilaksanakan oleh lembaga, artinya seluruh komponen yang ada di lembaga harus terlibat langsung sesuai dengan tugas dan tanggung jawabnya, serta c) hasil kegiatan pendekatan PDCA yang dilakukan oleh penilik terhadap LKP sesuai dengan fungsi manajemen menuju lembaga kursus dan pelatihan yang memiliki standar pelayanan 
minimal, serta kemauan dan inisiatif pengelola LKP untuk mengubah atau memperbaiki proses yang telah dan atau akan dilaksanakan guna perbaikan dan menuju pada layanan yang prima.

Kedua, rekomendasi kepada Dinas Pendidikan Kota Bandung dalam hal ini ditujukan kepada penilik kursus selaku pembina teknis dalam kegiatan pengendalian mutu program satuan PAUDNI, bahwa pendekatan PDCA dapat diimplementasikan dalam proses kegiatan pengendalian mutu di LKP.

Ketiga, rekomendasi kepada para peneliti berikutnya sebaiknya melakukan penelitian tentang perencanaan pengelolaan minimal LKP dengan pendekatan PDCA, agar dapat dijadikan rujukan penelitian yang lebih luas.

Kegiatan pengendalian mutu satuan pendidikan lembaga kursus dan pelatihan dapat dilaksanakan dengan menggunakan pendekatan PDCA untuk mewujudkan kinerja lembaga kursus dan pelatihan sesuai dengan Standar Nasional Pendidikan dibarengi dengan komitmen dan integritas pemangku kepentingan khususnya penilik untuk mewujudkan quality improvement.

\section{DAFTAR PUSTAKA}

Akhyar, Y. (2008). PDCA cycle (plan, do, check, and action). Diakses dari https://yayanakhyar. wordpress.com/2008/06/30/pdca-cycle-plando-check-and-action/

Baswedan, A. (2015). Pidato hari pendidikan nasional. Diakses dari http://kebudayaan. kemdikbud.go.id

Direkorat Jenderal Pendidikan Nonformal dan Informal. (2010). Apa dan bagaimana: Pembinaan kursus dan kelembagaan. Jakarta: Direktorat Pembinaan Kursus dan Kelembagaan .

Hiryanto. (2010). Makalah pelatihan penilik. Yogyakarta

Fattah, N (2012). Sistem penjaminan mutu pendidikan. Bandung: Rosda Karya.

Nawawi. (2003). Metode penelitian bidang sosial.
Yogyakarta: Gadjah Mada University.

Peraturan Menteri Pendidikan dan Kebudayaan No.

81 Tahun 2013, tentang Satuan pendidikan nonformal

Permenpan dan RB Nomor 14 Tahun 2010 tentang Jabatan fungsional penilik dan angka kreditnya.

Prihantoro, R. (2012). Konsep pengendalian mutu. Bandung: Rosda Karya.

Sugiyono. (2015). Memahami penelitian kualitatif. Bandung: Alfa Beta.

Undang-Undang Nomor 20 Tahun 2003 tentang Sistem pendidikan nasional.

Akhyar, Y. (2008). PDCA cycle (plan, do, check, and action). Diakses dari https://yayanakhyar. wordpress.com/2008/06/30/pdca-cycle-plando-check-and-action/ 